\title{
Information System of Cash Flow Analysis for Determining Company's Health
}

\author{
Muhammad Reza Qomarullah \\ Department of Information System \\ Diponegoro University \\ Semarang Indonesia
}

\author{
Retno Kusumaningrum \\ $\mathrm{PhD}$, M.Kom \\ Department of Informatic \\ Diponegoro University \\ Semarang Indonesia
}

\author{
Catur Edi Widodo, PhD \\ MT \\ Department of Physics \\ Diponegoro University \\ Semarang Indonesia
}

\begin{abstract}
This study aims to results information system of cash flow Analysis to determine company's health. Cash flow analysis in the form of a cash flow statement describing the receipt, cash disbursement and final cash balance in a period for monitoring and decision making. Cash flow analysis is classified into three activities, namely cash flow from operating activities (OCF), cash flow from investing activities (OCF), cash flow from financing activities (OCF). This study took samples on companies listed on the BEI and equaled namely Mahaka Media Tbk and ABM Investama Tbk. The results of this study show that ABM Investama is a healthy company because the value of OCF in positive (+), while at Mahaka Media Tbk is an unhealthy company because the value of OCF is negative (-).
\end{abstract}

\section{General Terms}

Cash Flow Analysis

\section{Keywords}

Information system, Cash flow analysis, Operational cash flow, Financial cash flow, Investing cash flow

\section{INTRODUCTION}

The ASEAN Economic Community (MEA) brings increasingly intense competition in various industries. In the current era of globalization every company / institution both government and private are required to be able to adjust to the development so that information can be obtained quickly, precisely and accurately. For that company must be able to face intense competition in the field of industrinya especially a company manager must be able to analyze the company's health and evaluate early on how much cash the company has to avoid bankruptcy in the company.

Information system to determine the company's financial condition and determine the health of companies that can know the real state of the company. Cash Flow Analysis is a way to know the financial condition of the company because this analysis reflects the actual state of the company, which in the analysis will look cash inflows and cash out of business activities used as a tool of financial analysis is very important for the leadership of the company.

This analysis it will be able to know how much funds needed to be able to finance the company's operations and can enable the company to operate as efficiently as possible and can control financial difficulties. Many countries in Mexico tend to use cash flow in their judgment decisions, whereas nonprofessional United States nations have a tendency to use earnings in their judgment decisions, so that there is a lot of corporate bankruptcy in the United States (Jose, 2012).

Cash Flow Analysis makes accrual manipulation more transparent and helps to limit earnings management. Issuing cash flows also increases the likelihood of reported cash flows to predict future cash flows and reduce abnormal cash flow operating operations in the following years (Christoper, 2011). Cash flow reports can also provide useful information for performance evaluation. Financial ratios can be calculated and used to measure liquidity, asset and management debt, profitability and performance. The ability to generate future cash flows and cash flows is very important, therefore the financial success of an entity is seen from how it generates enough cash to cover operations, current liabilities, interest payments and dividends and reinvest assets (Leonie, 2005).

Cash flow studies show the value of cash flow data in predicting bankruptcy and financial distress. An entity will not go bankrupt because its report is a net loss, but because it runs out of cash (Giacomino and Mielke, 1993). Cash flow plays an important role in corporate financial management tasks. For example, in liquidity management to ensure solvency and risk management to identify and protect the value of exposure due to foreign business activity (Sebastian, 2015). Many companies that generate large profits and have a lot of assets but the company can immediately bankrupt because of insufficient cash for debt repayment maturity or surgery soaring to know the health condition of companies need the role of information technology that provides effectiveness and efficiency to support activities company with an analysis that can describe the real cash situation is by using Cash Flow Analysis.

Based on the above problems the goal to be achieved in this study is to apply Cash Flow Analysis information system to determine the health of the company. With the development of information systems Cash Flow Analysis is expected to be useful for a company, especially for owners and investors to find out faster results of financial statements that are so that it can be a reference for the owner in knowing the state of his company. And for investors, help oversee the company he is financing, whether the company is in good shape.

\section{INFORMATION SYSTEM}

The Information System is a unified structure within an entity, such as a company, that employs physical resources and other components to transform economic data into accounting information, in order to satisfy the information needs of various users (Indrajani, 2008). information system is a set of interconnected components, collecting or obtaining, 
processing, storing, and distributing information to support decision making and oversight within an organization (Kenneth, 2007).

\section{CASH FLOW ANALYSIS}

Cash Flow Analysis is a method used to describe historical changes in cash and cash equivalents classified into operating, investing and financing activities during one period (IAI, 2011). Cash flow analysis in the form of a cash flow statement describing the receipt, cash disbursement and final cash balance in a period for use as accountability and decision making. The report also provides information on cash receipts and disbursements relating to operating activities, non-financial asset investments (Fitria, 2009).

Cash Flow Analysis is very important for investors and creditors, as they are more interested in assessing the company's ability to pay dividends and pay off its obligations. Investor demand for cash flow information has increased dramatically, leading to the growing popularity of analyst's cash flow forecasts in recent years. The literature on cash flow analysis can be divided into two streams. The first flow of literature demonstrates the role of cash flow play analysis in monitoring managerial behavior (Linna, 2014).

Cash Flow Analysis estimates help reduce earnings manipulation and improve earnings quality. The second flow of literature investigates the usefulness of information in Cash Flow Analysis estimates (McInnis, 2011). Research by Call, Chen, and Tong (2009) also suggests that cash flow information is very helpful to analysts and investors to know the state of the company. Cash Flow Analysis is important because: (1) financial obligations are paid with cash not profits, (2) profitable activities do not always reflect the cash needed and vice versa positive cash flow is not always profitable, (3) profit-generating companies can go immediately bangkrupt due to inadequate cash for repayment of matured debt and (4) a solvable company may not necessarily generate profit in the initial period of its operation so as to know its performance performed cash flow analysis (Leonie, 2005). To facilitate the analysis of financial performance with Cash Flow Analysis method, it is necessary to prepare a cash flow statement. This analysis was selected into 3 main activity groups as trichotomy cash flow (Nurul, 2009) is cash flow from operating activities (OCF), cash flow from investing activities (ICF), cash flow from financing activities (FCF).

Operating cash flow activities shall be cash arising from the operations of the enterprise relating to revenue, expenses, revenues and expenses. OCF is presented as a reconciliation of accrual net income into net cash flow from operations (Frank, 2014). OCF produces more accurate predictions about bankrupt and non-banker companies which indicate that operating cash flows are useful in descriptive and predictive research involving corporate finance (Cornelius, 1985). OCF is considered an important input entered by equity investors when assessing a company. If a positive OCF (+) means a healthy company, if a negative OCF (-) means a sick or bleeding company (Piyaratt, 2006).

Many previous studies investigated the usefulness of cash flows by examining the ability of earnings, cash flow, and component accruals to predict future outcomes and the extent to which they are reflected in stock prices (Qing, 2017). The cash flows in and out of operating activities include among others: a. Incoming cash flows from the sale of goods and services, dividend income, interest income, and other operating receipts.

b.Cash outflows for payments to suppliers of goods and services, payments to employees, interest paid on company debt, tax payments, and other operating expenses (Listyorini, 2013).

Investing cash flow activities are cash arising from investing activities or related to the sale of assets. Some examples of cash flows arising from investment activities are: Cash payments to purchase fixed assets, intangible assets and other long-term assets, including capitalized development costs and self-constructed fixed assets, Cash receipts from sale of land, buildings and equipment, and other intangible assets and other long-term assets, Cash payments to purchase debt instruments or other equity instruments and joint venture ownership, Advances and loans extended to other parties, Cash receipts from advance payments and loans extended to parties others given to other parties (Listiyorini, 2013). If the positive ICF (+) means the money goes to the company. If ICF is negative (-) it means money goes out of the company. Continuous positive ICF is actually not good because it means the shareholder / owner must continue to deposit capital to finance the company. The negative (-) ICF is just as good as the company making money for shareholders.

Financing cash flow activities are cash arising from the activities of debt from other parties. Examples: loans from banks, loans from moneylenders, loans from cooperatives, and payment of the principal of these debts. Some examples of cash flows arising from financing activities are: Cash receipts from the issuance of shares or other capital instruments, Cash payments to owners to withdraw or redeem entity shares, loan repayment, cash receipts from bonds emissions, loans, notes, mortgages and term loans short and long term (Listyorini, 2013).

FCF is said to be positive if it accepts debt and is negative if it pays the debt. But the FCF is said to be good if it poses a positive OCF impact, meaning money coming from debt raises income. So the company can pay its debts. Conversely, if FCF is negative, it means dangerous because the money that comes in does not generate profit. So the company can not pay its debts. The following illustrates the flow of firms that classify OCF, ICF and FCF shown in Fig.1.

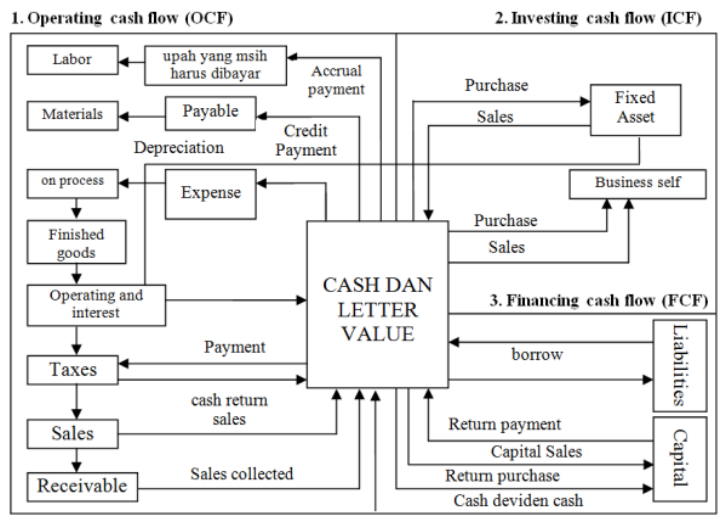

Figure 1 : Trichotomy cash flow

\section{DESIGN OF STUDY}

The research procedure in this research begins by performing the requirement analysis phase to identify the things needed in the implementation of software manufacture. The next stage of the design that translates the results of needs analysis into a form that is easily understood by the user. The next stage is the 
implementation that translates the data or problem solving that has been designed into the HTML, and the last stage is the testing phase which is the test phase against the software built. In order for this research to be more focused then used steps in the research procedure, the research procedure performed can be seen in Fig. 2.

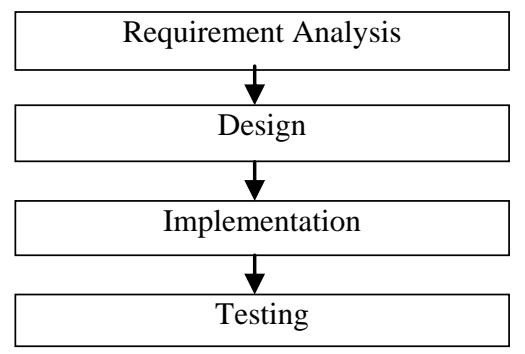

Figure 2: Research procedure

\subsection{Materials Research}

The research material in this research is in the form of company's financial statements of income statement and balance sheet of finance obtained from Indonesian Capital Market Dictionary (ICMD) and official website of Indonesian Stock Exchange www.idx.co.id.

\subsection{Context Diagram}

The design phase of this research starts from the context diagram. The following context diagram on the development of Cash Flow Analysis information system shown in Figure 3

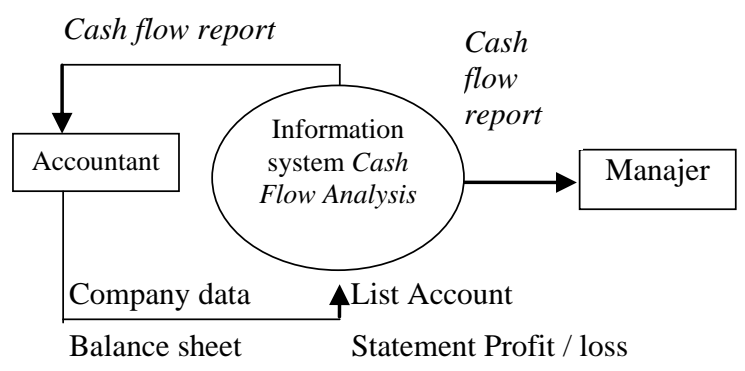

Figure 3: Context diagram

\subsection{Zero Level Diagram}

The next design stage in this research is the zero level diagram. The following zero level diagram on the development of Cash Flow Analysis information system shown in Fig. 4.

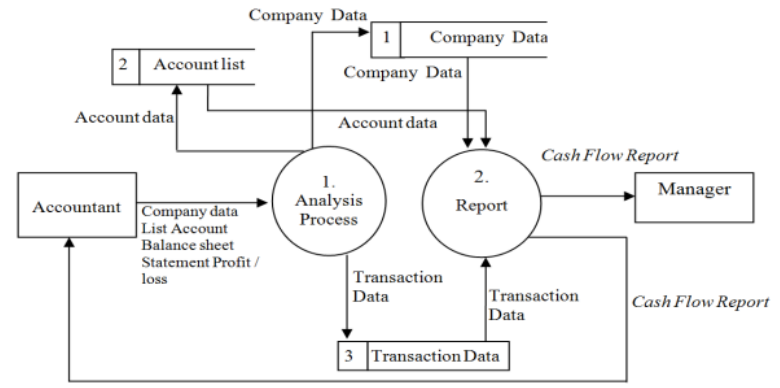

Figure 4: Zero Level Diagram

\subsection{One Level Diagram}

The next design stage in this research is the one level diagram. One level diagram chart on the development of Cash Flow Analysis information system shown in Fig. 5

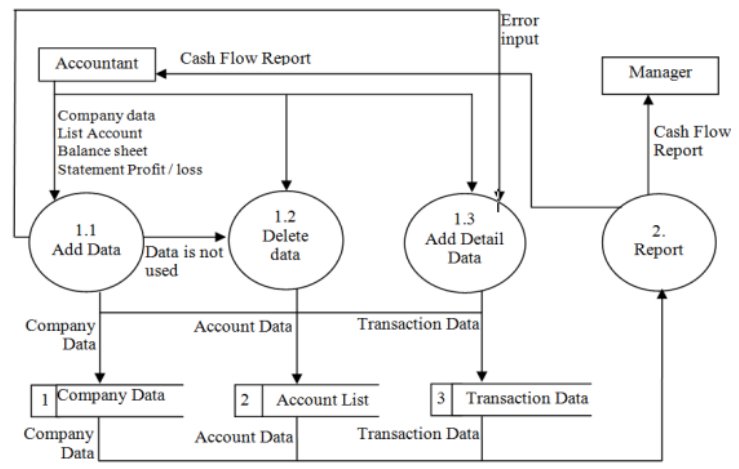

Figure 5: One Level Diagram

\subsection{ER Diagram}

The ER Diagram information system of Cash Flow Analysis is shown in Fig.6

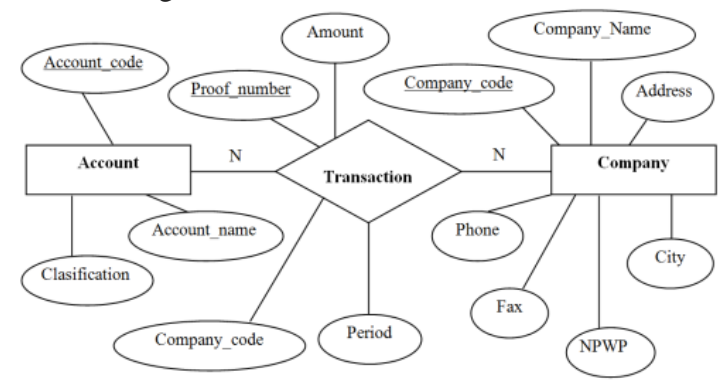

Figure 6 : ER Diagram

\subsection{Physical Data Model}

\subsubsection{User Login Table}

User login table used to store users who can login, as shown in Table 1.

\begin{tabular}{|c|c|c|c|}
\hline Attribute & Tyne & Lenoth & Detail \\
\hline $\begin{array}{l}\text { User } \\
\text { name }\end{array}$ & Varchar & 10 & User (pk) \\
\hline Password & Varchar & 10 & Wordkey / code \\
\hline
\end{tabular}

\subsubsection{Company Table}

Company table used to store companies, as shown in Table 2.

Tabel 2: Costumer

\begin{tabular}{|l|c|c|c|}
\hline Attribute & Type & Length & Detail \\
\hline $\begin{array}{l}\text { Costumer } \\
\text { code }\end{array}$ & Varchar & 30 & $\begin{array}{c}\text { Costumer } \\
\text { code }(\mathrm{Pk})\end{array}$ \\
\hline $\begin{array}{l}\text { Costumer } \\
\text { name }\end{array}$ & Varchar & 10 & $\begin{array}{c}\text { Costumer } \\
\text { name }\end{array}$ \\
\hline Address & Varchar & 40 & $\begin{array}{c}\text { Costumer } \\
\text { Address }\end{array}$ \\
\hline City & Varchar & 20 & $\begin{array}{c}\text { Costumer } \\
\text { city }\end{array}$ \\
\hline Phone & Int8 & & $\begin{array}{c}\text { Costumer } \\
\text { phone }\end{array}$ \\
\hline $\begin{array}{l}\text { Fax } \\
\text { Number }\end{array}$ & Int8 & & $\begin{array}{c}\text { Costumer } \\
\text { Fax }\end{array}$ \\
\hline NPWP & Int8 & & $\begin{array}{c}\text { Costumer } \\
\text { Tax Number }\end{array}$ \\
\hline
\end{tabular}


3.6.3. Account Table

Used to store accounts in transactions as shown in Table 3.

Table 3: Accounts

\begin{tabular}{|l|c|c|c|}
\hline Attribute & Type & Length & Detail \\
\hline $\begin{array}{l}\text { Account } \\
\text { Code }\end{array}$ & Varchar & 10 & $\begin{array}{c}\text { Account } \\
\text { code }(P k)\end{array}$ \\
\hline $\begin{array}{l}\text { Account } \\
\text { name }\end{array}$ & Varchar & 40 & $\begin{array}{c}\text { Account } \\
\text { name }\end{array}$ \\
\hline $\begin{array}{l}\text { Clasificati } \\
\text { on }\end{array}$ & Varchar & 30 & $\begin{array}{l}\text { Characterist } \\
\text { ic account } \\
\text { transaction }\end{array}$ \\
\hline
\end{tabular}

\subsubsection{Transaction Table}

Used to store transactions that occur on the compny as shown in Table 4.

Tabel 4: Transaction

\begin{tabular}{|l|c|c|c|}
\hline Attribute & Type & Length & Detail \\
\hline $\begin{array}{l}\text { Proof } \\
\text { Number }\end{array}$ & Varchar & 10 & $\begin{array}{c}\text { Transaction } \\
\text { proof number } \\
(P k)\end{array}$ \\
\hline $\begin{array}{l}\text { Costumer } \\
\text { code }\end{array}$ & Varchar & 30 & $\begin{array}{c}\text { Costumer } \\
\text { code }(F k)\end{array}$ \\
\hline Period & Varchar & 10 & $\begin{array}{c}\text { Transaction } \\
\text { time }\end{array}$ \\
\hline $\begin{array}{l}\text { Account } \\
\text { Kode }\end{array}$ & Varchar & 60 & $\begin{array}{c}\text { Account } \\
\text { code }(F k)\end{array}$ \\
\hline Amount & Int8 & & $\begin{array}{c}\text { Tranaction } \\
\text { amount }\end{array}$ \\
\hline
\end{tabular}

\section{RESULTS}

\subsection{Cash Flow Analysis of ABM Investama Tbk}

The result Cash Flow Analysis of ABM Investama Tbk as shown in Fig. 7.

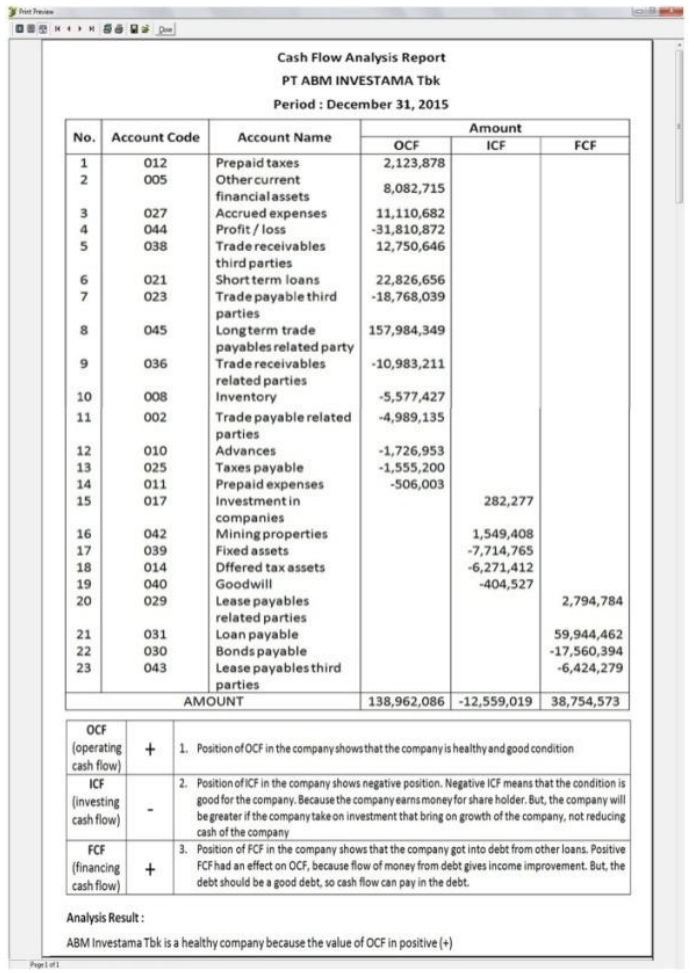

Figure 7 : Cash Flow Analysis of ABM Investama Tbk
From Result The above analysis produces the following cash flow statement: OCF: 138.962.086, ICF: -12.559.019, FCF: 38.754.573. The results of the cash flow statement explain. ABM Investama Tbk is in good health because OCF from ABM Investama is in Positive (+). Being reinforced by the ICF value in negative (-) circumstances which means the company is making money for its shareholders. Thus from the financial statements. 2008 Annual Report ABM Investama Tbk produces such a company in generating profits, developing and in good health with proven positive OCF (+).

\subsection{Cash Flow Analysis of ABM Investama Tbk}

The result Cash Flow Analysis of Mahaka Media Tbk as shown in Fig. 8 .

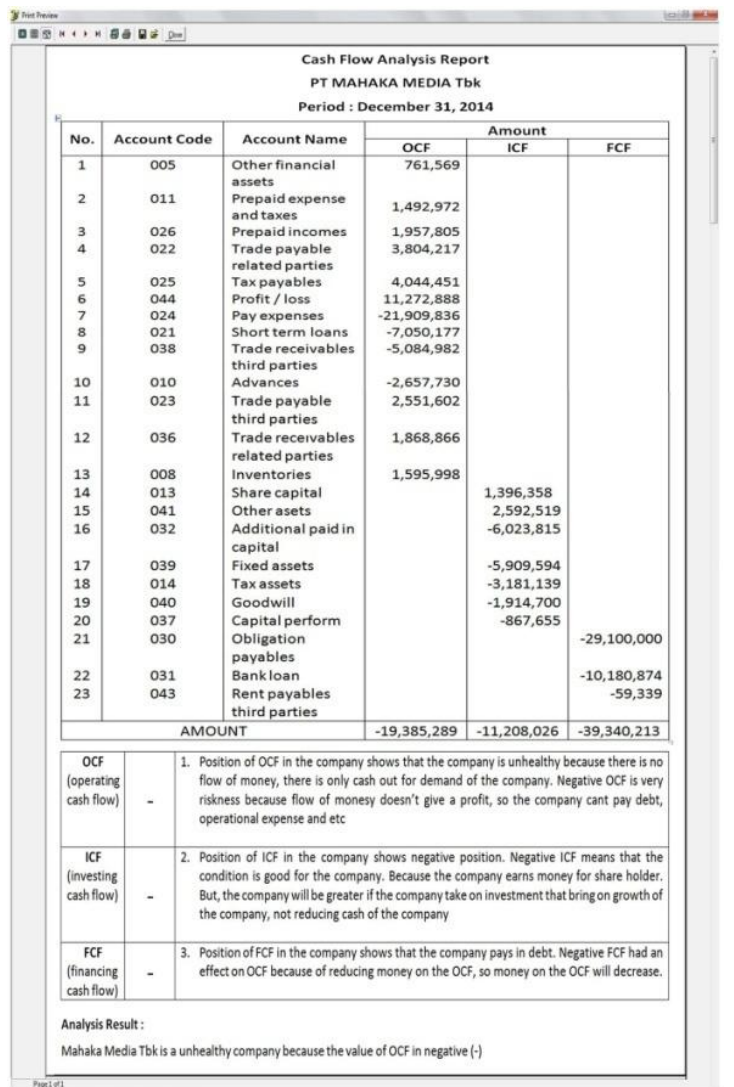

Figure 8 : Cash Flow Analysis of Mahaka MediaTbk

From the above analysis results generate cash flow report as follows: OCF: -19.385.289, ICF: -11.208.026, FCF: 39.340.213. The result of Cash Flow Analysis report explains that Mahaka Media Tbk is in an unhealthy / problematic condition because OCF from Mahaka Media Tbk is in negative condition (-). This means that the distribution company operations are not healthy. In a sense, during the operation, the company has a relatively small amount of expenditure or income. If allowed, the company will collapse because it can not repay various loans. Companies with negative OCFs (-) indicate the company is in a losing state because there is no cash in running the company. Thus, from the profit and loss statement and the Balance Sheet Report at Mahaka Media Tbk result that the company is not developing and in an unhealthy condition with proven to have negative OCF. 


\section{CONCLUSION}

The conclusions obtained based on the results of research on Cash Flow Analysis information system is by using Cash Flow Analysis in this study can be seen that the ABM Investama Tbk generate OCF value of 138.962.086, ICF value of -12.559.019 and FCF value of 38.754. 573, meaning ABM Investama Tbk is a healthy company because the value of OCF in positive state (+) and ICF position is also in a negative state, meaning ABM Investama Tbk shows the company is making money for the shareholders / owner. While at Mahaka Media Tbk produce value of OCF equal to -19.385 .289 , ICF value equal to 11.208.026 and FCF value of -39.340 .213 , it means Mahaka Media Tbk is a company that is not healthy because the value of OCF in negative state (-).

\section{REFERENCES}

[1] Blanc, S.M., Setzer, T., 2015, Analytical debiasing of corporate cash flow forecasts, European Journal of Operational Research, Karlsruhe Institute of Technology, Germany, Vol.1 No. 243

[2] Burke, Q.L., Matthew, M., and Wieland, 2017, Value relevance of banks cash flows from operations, Journal of Accounting Research, Vol.10

[3] Call, A.C., Chen, S., \& Tong, YH., 2009, Are analysts earnings forecasts more accurate when accompanied by cash flow forecasts, Review of Accounting Studies, Vol. $14,358-391$

[4] Casey, C., dan Norman B., 1985, Using Operating Cash Flow Data to Predict Financial Distress: Some Extensions, Journal of Accounting Research, Vol. 23 No. 4, 384-401

[5] Edmonds, C.T., Jennifer, EE., and John, JM., 2011, The impact of meeting or beating analysts operating cash flow forecasts on a firm's cost of debt, Journal of Accounting Research, Vol. 27, 242-255

[6] Frank, R., 2014, The power of cash flow ratios, Department of Accounting, University of South Alabama, United States

[7] Giacomino D.E., David, E.M., 1993, Cash flows : another approach to ratio analysis, Jurnal Accountancy, Vol.175, No.3, 55-58
[8] Indonesian Accounting forum, 2011, finance Accountancy Standard Declaration, Salemba Empat, Indonesian

[9] Indrajani, 2008, Data Principle system of Five Package In One, Elex Media Komputindo, Indonesian

[10] Jantadej, P., 2006, Using the combinations of cash flow components to predict financial distress, Doctoral Dissertation, University of Nebraska, Lincoln, Nebraska

[11] Jooste, L., 2005, An evaluation of the usefulness of the cash flow statement within south african companies by means of cash flow ratios, Doctoral Dissertation, Faculty of Economic and Management Sciences, University of Pretoria, South Africa

[12] Kenneth, C.L., \& Jane, P.L., 2007, Management Information System, Book I, Edition 10, Salemba Empat, Indonesian

[13] Latifah, N., 2009, performance measurement company's finance with method cash flow ratio analysis, Economy Focus, Vol. 4 No. 2

[14] Marisya, F., Khairani, S., 2009, Analysis method Cash Flow Reporting in Cahaya Fajar Indonesian company, Accountancy journal, STIE MDP, Palembang

[15] McInnis, J., Collins, DW., 2011, The effect of cash flow forecasts on accrual quality and benchmark beating, Journal of Accounting and Economics, Vol. 51(3), 219239

[16] Miranda, J.E., 2012, The use of earnings and cash flows in investment decisions in the U.S. and Mexico: Experimental evidence, Journal of International Accounting, Auditing and Taxation, Vol. 21, 198-208

[17] Shi, L., Huai, J., dan Jun, G., 2014, Analyst cash flow forecasts and pricing of accrual, Jornal of Accounting, Vol. 30, 95-105

[18] Wahyu, L., 2013, Acurated Cash flow model with direct method and indirect method to predict future dividend, Research Statement, University of Stikubank, Indonesian 